\title{
Contemporary Religious Violence and the Environment: Some Tentative Observations and Assessments
}

\author{
R.E.S. Tanner and C.J. Pawson
}

\section{INTRODUCTION}

It is perhaps generally assumed in developed societies that religion as a motivating force is of diminishing importance. This comfortable theory based on rational man ignores the destructive power of religion in contemporary wars and civil wars and its consumption of materials. Thus it is a fact in the contemporary world that religious motivations can have an active effect on the environment. Furthermore this effect is in the main destructive.

Violence in the context of the environment is taken to be the killing, transformation or destruction of any animate or inanimate object for which the primary reason is religious. This would include crusades, pilgrimages, martyrdoms, terrorism, sacrifices, wars, civil wars and geno-cide. This assessment of the environmental impact of religious violence is based on the assumption that it is global in scope rather than directly or indirectly to the survival of humans alone. There are difficult questions as to what constitutes an environment over which we have collective anxieties other than some generality 'out there' in which we as individuals and groups are not directly involved.

Some questions that need to be addressed are a. When does a micro- become a macro environment in which we should have legitimate concern? The kissing of an icon in a Greek Orthodox church prior to warfare against Muslims at least prepares them for violence and environmental damage. This could be assessed as destructive.

b. There is the question of how far a destructive influence operates from its initial point. The range of influence in terms of square kilometres and the number of species or the number of humans affected. Refugees from religiously based warfare spread diseases from their concentrations of humans and the sheer number of their contacts.

c. In addition these same influences have to be assessed in terms of how long they will last. The killing of large numbers of young men in religious conflict has an effect, which lasts for at least a generation for they cannot breed. Unexploded munitions remain dangerous indefinitely.

d. Finally an effect on the environment for religious reasons can fluctuate between benign and malign depending on the range of its effects and the time span of these effects. There is no doubt that the indiscriminate sowing of landmines in Afghanistan is good for the environment on both counts as it allows the natural regeneration of impoverished soils and vegetation, but bad in the short-term for humans and livestock.

\section{Religions and the Environment; An Overview}

In simple terms there appear to be three types of religions which can have effects on the environment. Firstly, the religions of the book: Christianity, Islam and Judaism. These religions, based on sacred writings, are used during a single life from which there are eschatological benefits. Their tenets are individualistic and any behaviour which is going to have an effect on the environment is likely to be based on small theocratic Christian communities such as the Amish (Hostetler, 1970), the Hutterites (Hostetler and Huntington, I974) and the Mormons (Francaviglia, 1978). With Jews there are the imposed ghettoes and with Islam some concern over the use of water supplies. It is not the aim of these faiths to have an environmental effect as they are one-human-life centred exerting direct influence on some individuals combined with long-term indifference.

The second type of religions which have some direct influence are the eastern religions, Buddhism and Hinduism in which the individuals through the transmigration of souls have an infinite number of future lives. Individuals by their personal self-abnegation can improve their position in their futures lives. This leads to religious centres becoming nature reserves, vegetarianism, the avoidance of killing even insects by accident as with the Jains (Dundas, 1992), and in the return to their habitats of captured birds and other animals. Seeing cows on the streets of Indian cities immediately raises environmental issues, 
whereas the consequences of Jain behaviour are socially and biologically invisible. Similarly, these religions exert some widespread direct influence within long-term indifference because of their multiple future lives.

A potential third type of religion is the preliterate religions of tribal peoples in which the living, the dead and the unborn form a familial continuum. Environmental success for such groups is at the expense of other groups. There appear to be no overall beliefs or practices that could have widespread effects, but for the small group, environmental balance supported by religion correlates to survival.

\section{Religious Violence and the Environment in History}

Historically religions have been extremely destructive of human populations and their environment apart from their responsibility for the spread of disease (Reynolds and Tanner, 1995, Chapter 13). In 189333 thousand pilgrims died in and around Mecca and the dead remained unburied (Izzedine.no date). Enormous númbers died regularly from cholera following Hindu pilgrimages

It is not so much the numbers who have been killed historically for religious reasons but their proportion to whole populations. The Taiping Rebellion in China.1851-64 under a leader claiming to be the brother of Jesus Christ (Boardman, 1952) may have killed up to 20 million people so that in some cities only dogs survived (Wakeman, 1966). Tamurlane killed from piety (Groussert, 1970) about $80 \%$ of the populations along the belt of Arab-Iranian civilisations (Lamb.1932); his men are said to have piled 70 thousand heads outside the walls of Isfahan. At the Christian siege of Damietta in 1219 only 3000 Moslems out of a population of 80 thousand survived (Oliver, 1894). These are very high proportions of these populations significantly reducing their pressure on their environment.

More recently the Turkish killing of some 35\% of Armenians in 1915-17 (Boyajia, 1972) does not quite reach up to the same levels of environmental relief although the figures will be higher if emigration is included. The killing of over 10 thousand Mahdists in the Sudan at the battle of Omdurman in 1893 (Levy, 1974) would probably be about the same level of population reduction.

Some better-known historical massacres would have had little environmental effect. The St Bartholemew's massacre of Protestants by Catholics in France only killed 1\% of that population (Benedict. 1991). Much the same applies to Jewish pogroms in Russia and Poland over the end of the last century rising to an estimated 60 thousand killed in 1917-21 mainly by the White Ukrainian Army in 887 major and 349 programs (Encyclopaedia Judaica, 13: 694701(1971)). Finally the Holocaust killed off whole Jewish communities in a return to the population obliterations of Tamurlane, with an estimated 6 1/2 million Jews killed in all between 1933 and 1945.

\section{Religious Violence; The Continuation in History}

A study of 106 wars between 1820 and 1952 (Wilkinson, 1980; Richardson, 1950) showed that differences of religion were frequently cited in the sources as a cause of fighting in $35 \%$ of interreligious pairs with different beliefs about the world in general having been the cause of fighting in $16 \%$ of all belligerent pairs. Three quarters of all inter-religious pairs had a Christian member and $90 \%$ of all fighting between co-religionists was Christian. Only $10 \%$ of wars had neither a Christian nor Moslem component. This has led some commentators to conclude (Wilkinson, 1980; Wright, 1964) that Christianity and Islam strongly incite their members to fight those of other religions or incited those other religions to fight them or that these two faiths especially incited their members to fight one another.

Are current religions associated with warfare to any lesser or greater degree? Lebanon (Christianity versus Islam), Israel (Judaism versus Islam), Sudan (Islam versus Christianity and African traditional religions), Sri Lanka (Buddhism versus Hinduism), Iran/Iraq (Shia Islam versus Sunni Islam), Afganistan (Islamic civil war), Yugoslavia (Christianity versus Islam), Cyprus (Christianíty versus Islam), Ulster (Roman Catholic versus Protestant Christianity) and south-eastern Russia (Christianity versus Islam). This list could be extended further by including conflicts in which Christianity fights Communism, as well as in Kashmir, India and Pakistan (secular Hinduism versus Islam) where there have been three wars and continuing tensions. The attack on the World Trade Centre in New York in September 2001 killing some three thousand people was religiously motivated 
as was an early gas attack in the Tokyo subway by members of a Japanese sect. Thus it would seem that there has been no let up in what might be categorized as wars in which differences of religious beliefs are at least one of the principal motivating forces. There are newspaper photographs of weapon training in mosques and mullahs with their kalashnikovs just as there are pictures of Christian priests shooting in the Lebanese civil war with pictures of Our Lady on their rifles.

Some of these current religious wars are no more than continuations of older quarrels dating back centuries as in the ex-Yugoslavia where Christians and Moslems are still reacting to each other in terms of past Turkish dominance. Others in the Lebanon are continuations of circulating tensions between Christian, Druzes, Jews and Muslims in which each religious community has been the object of periodic massacres. The present latent, continual and widespread tension between Greece and Turkey in the Aegean and Cyprus dates from the Middle Ages.

Have there been any changes since 1945 ? In the past Christians have been way ahead in bellicosity with Islam some way behind but this balance appears to be changing so that Islam is becoming the most bellicose religion, whether or not terrorism is included in Israel, Egypt, Algeria and Northern Ireland in which religion is the main category distinguishing protagonists.

In sociological terms Islam with its small range of religious requirements fulfilled by action rather than attitude combined with belief in heavenly rewards, appeals far more cogently to those who have not benefited from economic and social development. Islam is likely to appeal much more in the future and to cause more ideological trouble with environmental effects than the exChristian societies of the west which do not appear collectively to believe in anything sufficiently strongly to fight for it on religious grounds except for a few small fundamentalist groups.

The incitement to violence is obvious to any reader of the sacred literature of both Christianity and Islam. They are full of violent language; the battle and victory against sin is one of the commonest. This forms an important current part in religious nationalism (Juergensmeyer.1993). 'Onward Christian soldiers' and 'Fight the good fight' are still popular Protestant hymns in English. Overall there are no grounds for thinking or planning on the assumption that such quarrels essentially based on religious differences are becoming less vicious and destructive.

Only in one respect are religions less environmentally destructive than they used to be and that is in the spread of known epidemic diseases. Refuge routes may be no longer the channels along which diseases flow and refugee centres are no longer the foci for the outbreaks of mass diseases.

\section{Contemporary Warfare and the Environment}

The environmental effects of such extensive wars are often visually obvious as with the devastation of Beirut and Sarajevo after years of civil war with sophisticated weapons. Firstly it takes certain areas out of human use for variable periods. In terms of biology the destructive effects of warfare are surprisingly short-term; nature recovers remarkably quickly. In the tropics a battlefield is nearly unrecognisable after two years; the effects have to be looked for. In deserts warfare does not matter and indeed it is probably the best place for fighting as groups of breeding males only destroy themselves in waterless wastelands of stone and sand. In terms of species survival, warfare is no more than a hiccup in time, much less destructive of environments than the proliferation of the omnivorous goat.

Secondly it reduces population pressure by destroying surplus numbers of young men who are not able to reproduce. The killing of an estimated hundred thousand men in the Iraq -Iran war could be seen as an environmental success allowing those countries a breathing space to develop more for the maintenance of their too rapidly expanding populations. However as in the current Afghan war dead fighters would have their widows absorbed into polygynous marriages ever since the battle of Badr in which the Prophet Mohammad encouraged the surviving men to marry the widows of those killed for their new faith. Christian warfare has the advantage of leaving large numbers of non-breeding widows

Since the rapidly expanding population of Sri Lankha correlated to the 1947 DDT campaign against the malarial mosquito which doubled the island's people in 17 years, the civil war between Buddhists and Hindus could also be seen as environmentally advantageous except in the sense that the killing has not yet reached high enough levels to relieve overcrowding.

Warfare in populated areas also reduces livestock pressure on land. Armies are often either 
poorly fed or want variety so that any edible animal in the fighting area tends to be killed off if not hidden; chickens, pigs, sheep, goats and cattle are eliminated. Many third world areas are grossly overstocked and in this respect civil wars are better as they tend to last longer than wars and their effects are more widespread. The recent civil war in Ruanda between Christianised tribes have killed off both livestock and several hundred thousand humans in a country with very high population densities. In the sense that Christian values had no effect on this mass killing, its lack of influence was environmentally benign.

Finally warfare moves populations away from the areas of warfare into refugee camps in which they would die in larger numbers than they do but for aid motivated at least in part and in origin by Christian obligations to help those to whom they are not related; in this sense Christian aid prolongs the population in marginal areas incapable of sustaining high population densities as in Somalia. These camps disproportionately kill off the old and the young. The women there who live on nutritionally low diets for prolonged periods are unlikely to become fertile since their menstruation becomes irregular or stops altogether.

The significance of contemporary religious warfare on population levels has perhaps not been fully recognised because the totals are not high enough to merit mass media attention. If the Ulster Protestant v Roman Catholic figures for 196981 were applied proportionately to the United States, they would have had 282 thousand killed, two million injured and if applied to mainland Britain 75 thousand killed and three-quarters of a million injured (Hickley, 1984).

If economic waste is related to what might have been done to the environment in Northern Ireland the totals are horrendous. Over a hundred churches damaged or destroyed 1971-82, 28500 shooting incidents, 7200 bomb explosions plus 3200 bombs defused, 2300 deaths(O'Malley, 1983). This is a civil war between two Christian groups, more or less fundamentalist Protestant Christians led by their clergy who talk in terms of 'no surrender' and Roman Catholics who take little notice of their own clergy's admonitions to stop this violence.

Religious terrorism in which the initiators give their lives in a struggle on God's behalf (Rapoport, 1982)thus gaining immortality as with the Hamas bombings in Israel has little direct effect on the environment as the two religious communities involved are already segregated. Since the United States State Department estimated that only 8700 had been killed by terrorism 1968-95, the numbers killed are too small to have any direct environmental effect and the devastation is local and temporary. The crashing of aircraft into the World Trade Centre and the Pentagon killed off only a small number of fecund men and women but the placement of the rubble from the former buildings has had a major environmental effect near to New York.

Religious violence if it does not kill, separates populations. Like moves towards like and in anticipation of the 'other' taking over their property and land, as much as possible is destroyed; in Israel Jews have destroyed property in areas to be taken over by the Palestinians, and evacuating Christians in ex-Yugoslavia have burnt their houses rather than let them be taken over by the incoming Muslims. Such areas are environmentally neutralised and their populations have to be supported by others.

The effect of the Greek Christian attempt to dominate Cyprus and the mainland Turkish counter-invasion, effectively divided the island with very few Christians in the north and even fewer Muslims in the south, much the same as in Asia Minor where Greek Christian villages are still empty after the flight of their inhabitants in the early 20s. The result of these population movements of 20 years ago in Cyprus is still visible in the north with empty farms, closed shops, idle factories, and desecrated Christian cemeteries, whereas the forced evacuation of Cretan Muslims in the mid 20s is not so visible except architecturally. In both these cases the totals of killings were not enormous but the amount of land taken out of agriculture must have been high in terms of harvest yields. Thus such exchanges of populations on religious grounds may have been in the short run environmentally beneficial, while causing productive strain on other areas.

There is possibly another factor in religious segregation as in Belfast where $70 \%$ of the population lives in religious ghettoes of their own choosing after decades of mutual harassment. Any religiously segregated community like the Amish has increased inbreeding and the gene pool becomes restricted. This may well have environmental effects in reducing their reproductive rate if it is prolonged. 
Invasions of one religion into the territory of another may result in the unequal use of environmental resources. The Israeli occupation of Arab land has resulted in the unequal development in which the two communities in close proximity do not have equal access to resources. Newly created Israeli settlements will have clean piped water supplies and indeed swimming pools while the nearby Arab villages will have the women drawing impure water from wells with buckets and rope. This division is carried out by the power of the religiously motivated gun.

\section{Some Conclusions From the Available Data}

a. Religious violence takes two forms. One in which humans destroy humans and secondly in which humans destroy inanimate and animate materials and living matter. In both cases there are immediately visible as well as long-lasting environmental effects.

b. It would seem that religious violence, human to human, affecting the environment is now on the increase after a lull in the second half of the 20th century.

c. This increase may be due to the failure of secular economic and political systems to deliver their somewhat optimistic forecasts; the popular ideology of inevitable development as an individual right has failed.

d. This religious fighting is probably environmentally benign in both the short and long term as it reduces human and animal populations as well as periodically taking large areas out of human use.

e. Humans destroying non-human materials and animals for religious reasons has been and continues to be at the very least constant. It may in fact be on the increase as the developed societies use up more materials for religious purposes without replacing these environmentally. This indirect religious violence must be considered environmentally malign in both the short and long term.

f. The data discloses that in practice rather than in theory religions tend to be environmentally destructive in the short-term but benign in the long term. Where religious are active en masse, they destroy rather than preserve.

b. The more passive influences of religious practices on individuals and groups (Reynolds and Tanner.1983) tends to preserve them socially and biologically and enhance their potential for reproduction and thus possibly threaten the environment in the long-term. Where they do preserve the environment it tends to be in the form of religiously motivated 'zoos', small enclaves of accidental preservation.

\section{Conflict Genesis and Religious Violence}

Population pressure leads to pressure on resources but it seems doubtful whether this is seen by those involved as the primary cause of violence. Human societies quarrel over immediate issues that are popularly understandable and indeed find it easier to fight than to compromise. They find it easier to see their quarrels and difficulties in terms of race (visibly different), ethnicity (tribally different), nationality (politically different) and religion (ideologically different).

These themes are easier to understand and are more satisfying tools for mobilising effort than the environment which is a complex of issues for which a word may not exist in many languages, and which in effect only seems to be a matter of concern to those whose livelihoods are assured and who do not feel themselves threatened in any real pragmatic and personal way by their neighbours who are different to themselves. This is all the more inevitable as all humans are socialised from childhood to distrust, dislike and avoid outsiders

\section{The Environment and Metaphysical and Material Security}

Very few people in the contemporary world have any sense of material security, certainly not in the sense of institutionalised supports that are perceived as guaranteed for a lifetime. Even in national states that can economically provide comprehensive welfare systems, it is doubtful whether more than a small minority see themselves as secure since the concept of security changes with economic and social development and involves more psychosocial factors for which there are no answers.

Even the most comprehensive and effective welfare system does not eliminate threats from without and indeed such threats are inevitable for all human beings. Most people live under economic and social threats from people whom they assess as being different to themselves.

It is trite to state that security for individuals is for them to live out their lives without being 
faced with insurmountable difficulties; that is to say that outsiders are defining what is reasonable security. Most people are prisoners within a particular social system and outsiders tend to state that once a people are past Maslow's Stages 1 and 2 (Maslow, 1987), then they are materially secure and should thus be able to consider the environment.

Most people in developed societies would see environmental security as pleasant neighbours who are not socially polluting and that they should be able to walk on occasions through wellmaintained parks and an orderly countryside with not too much manure on the ground. Very few are prepared to deprive themselves for the benefit of the environment.

Many environmental concerns are facts because we are told that they are facts; we have no personal experience of them and they are beliefs which we have about AIDS, radiation sickness, BSE and soil exhaustion. In social terms they are presented as dogmas with the characteristics of religious ones which we are invited to believe because the scientific elite in our societies tells us that they should be believed and like other religious beliefs they are largely ignored.

\section{Religious Systems Affecting the Use of Natural Resources}

In theory secular rather than religious governments should be better able to restrict religious violence and to appreciate and promote the long-term value of a benign environment for their citizens. In practice there has been a growth in specifically religious nation states where once there were only the Vatican and Saudi-Arabia; now there are several Islamic Republics and of course Israel.

While Western secular states have a reasonable record in withstanding the demands of Christian pressure groups or more specifically preventing fundamentalism from turning to persistent violence, states with Muslim populations have had a continuing problem with violent fundamentalists who would be almost by definition oblivious to environmental issues.

At levels below that of the nation state, religions are not structures administratively or theologically capable of taking action to improve or indeed prevent the decline of the environment; it is not their job and moreover there is no public demand for any such change of focus. All religions focus on the individual's behaviour in relation to God(s) and their fellows; these are primary considerations and the environment is at best a tertiary consideration.

The difficulty may be that the environment is an abstract idea in which there are no real people except perhaps visitors and without a focus on individuals rather than groups the environment has no link up with religion except in the destructive events already described. The foci are individually eschatological rather than related to this life collectively for their own societies much less societies with which they have no contacts at all .

Religious emotions are to a large extent out of the control of religious authorities who usually do not incite their followers to violence. With Christianity in the past and with Islam today there seems to be an inbuilt aggressiveness. With the contemporary and continuing male dominance in Islam there seems to be a correlation with aggressiveness combined with a socio-religious reluctance to restrict breeding.

Where religions have been a benign influence on the environment, it seems to have been cultic and local rather than ethical and general. In all the cases listed religious aggressiveness seems to have struck a sympathetic chord within the individual and collective psyche which is usually outside the practical control of religious leaders whose public utterances and dogmatic beliefs have laid the foundations which others have found so useful to develop into aggressiveness.

\section{Conflicts Over Resources Affecting Environmental Controls}

It would seem that where there are physical conflicts, there is always territory at stake and that these territorial conflicts are given justifications which can be as easily religious as for any other reason. Whether religion initiates the push to dispute an environment or the need to occupy an environment initiates a religious justification, is probably answered by where in history the analyst starts looking for causes. An historically distant tertiary cause can be updated into violence as a contemporary primary cause as in Israel today.

In any society in which religion remains even of quasi-importance, much less dominance such as in Islamic states and in right-wing Hindu parties in India, threats to religion, however interpreted or rationalised, can easily become popular rallying cries. Hindus and Muslims have been at 
each others throats for centuries in India with a regularity which defies rationality; statistics show that it has been an almost seasonal activity. Protestants and Roman Catholics in northern Ireland seem to show the same persistent hostility to each other sparked off by the so-called marching season of Protestant parades as if this violence coincided with climatic and agricultural cycles.

In such situations elected governments as much as oligarchic ones, respond to the need to be easily popular by supporting such causes or use such popular causes as a way out of other difficulties. which may be as much secular as religious as in the recent Iran-Iraq war. The Shia Iranians responded to Sunni Iraqi aggression in a specifically religious way; it was perhaps accidental that they fought over oil-less desert.

\section{The Religious Perception of Resources and Environmental Changes}

Since religions are individually experienced but collectively expressed, Maslow's hierarchy of needs (Maslow.1987) seems a reasonable way of assessing the individual's relationship to the environment and from these to see the possible links with religion.

Stage I. Physiological needs. At this level survival is the only issue; in the individual need for food and water they will ruthlessly destroy any environment in the face of starvation, cutting down trees to get the fruit and occupying water holes by force to keep others away. In these circumstances individuals are self-centred and aggressive. There is not likely to be any collective activity at this level and no religious considerations are involved in famine situations. Of course in certain circumstances religious taboos will override the physiological need for food as has been recorded in Indian famines for Hindus. At this level the short-term environmental consequences are hostile to immediate human group survival but the long-term ones are likely to be beneficial.

Stage 2. Safety and protection needs. These are predominantly short term needs which are likely in some localities to be repeated year after year in contrast to Stage I physiological needs which are more likely to be occasional. Again they are likely to be destructive of the environment surrounding any groups seeking security as in the use of scarce materials for defence and over-cultivating near to the safety of villages.

On the other hand safety and protection needs can lead to the dispersal of human populations away from their normal habitats which will be to the long-term advantage of the environment. Wars in Southeast Asia had this effect. Religions may increase the need for safety and protection from persecution which can lead to concentrations of devotees as with the Alice Lenshina villages in Zambia and the movement of Mormons westwards into a waterless area which they dominated through innovative farming and water control. In this we see the beginning of perceived as opposed to real needs becoming dominant.

Stage 3.Belongingness and the need for affection. Once the earlier stage needs of the nuclear groups have been satisfied, the range of belongingness needs increases with the development of different larger groups, including religious ones, with which individuals and their families can become associated. It is possibly that the greater the needs which have been shown to exist in their social and geographical environment, the greater the need for these memberships.

Such religious groups can occupy territory and keep others out by force and being so successful in doing this that ultimately they either overrun their environment, causing its decline or the religious social system itself declines. In the short run the Amish system is environmentally beneficial but in the long-run less so. Aggression is now beginning to have an ideological tinge rather than being based on ordinary and acceptable necessity.

Stage 4.The need for esteem, prestige and status.This stage is likely to have the greatest effect on the environment since the higher the religious commitment of any community when viewed hierarchically, the greater the need to protect it. The Iranian leaders invoked religion as a means of resisting Iraqi aggression over territory which had little value as real estate as their prestige was at stake. The environmental effects on both sides of the border were probably benign as the loss of so many breeding males will have relieved population pressure in both the short and long-term.

Stage 5. Self-actualization needs and the removal of anomie. In this final stage religious leaders in relative security are in a position to attract followers and to initiate environmental change. We see this in Israel where Jewish aggressiveness in the planting of settlements in 
the occupied territories with high standards of living in such matters as the use of water alongside Palestinian Muslim villages with lower standards of living makes prolonged hostility inevitable from an increasing shortage of elbow room resulting from higher Palestinian birth rates.

Religious leaders from a secure dogmatic base which is their interpretation of God's word as in the present instances of Islamic and Christian fundamentalism can whip up hostility to outsiders which is extremely damaging in the short term but much more benign in the long run provided that the violent hostility is sufficiently intense and prolonged.

\section{Conflicts Over Resources Affecting Governance Structures}

It seems unlikely that except in situations where there is an already existing identifiable resource such as oil, that conflict in the popular mind will be directly related to resources. The successes of western scientific medicine in controlling mass diseases and the relentless work of aid agencies has led to population pressures everywhere. In both the mountains of Myanmar and the cultivation steppe of Tanzania humans have eaten up the land and its resources with the persistence and competence of insects.

For most of the world's population half-empty stomachs will act to promote violence for which any number of emotional triggers will be good enough. Democracy or 'anything for a quiet life' systems of popular government are perhaps no better than fascist or oligarchic political systems in thwarting pressures for immediate improvements in standards of living; the popular framework of thinking or rather hoping is almost always short term.

Certainly population pressure reduces elbowroom and few see the logic of depriving themselves of children now for highly speculative longer-term benefits. If those they are rubbing up against have a different religion demonstrated officiously by temples, mosques, churches and synagogues, then the religious tail will wag the secular dog.

Scientific facts can be argued about and perhaps knitted together into semi-rational but useful compromises but ideological arguments based on the printed words of God do not have this plasticity. The Mediterranean single life religions have an in-built tendency to fight over territory that is seen as a spiritual rather than material resource whatever it contains.

\section{The Perception of Environmental Change}

Most people everywhere have a 'golden age' perception of the past and the oral memories of most of the people of Asia and Africa are of a past without guns, colonialism, population pressures, desertification, famine, drought, mass diseases and in eastern Africa without the spread of the tsetse fly. It is a perception of the past that never existed.

For a short time during the de-colonialisation era there was a widespread 'golden future' perception of what would happen from the end of European domination and the disappearance of white administrators and professional controllers. This has now largely disappeared in a plethora of corruption, disorders, AIDS and inequality.

The people are in the main subsistence farmers for whom the immediate future will always be problematic so that their framework of thinking is short-term. Some languages have no indefinite future tense with which to think about long-term environmental issues but they also have no word for the environment beyond what might be called 'the neighbourhood', which in effect means 'out of sight, out of mind'; a small environment with a socially limited horizon .

Religious taboos may protect small spiritfilled localities but no religion has any enforceable moral ideas which relate to the environment since they are all here and now in this life people centred; they help people cope with their present problems and not those of their grandchildren yet unborn.. Even the word 'environment' has a detached depersonalised tone to it. Perhaps one can conclude that land as property will be fought over for as variety of reasons including religion, but never in order to protect the environment.

In the developed world it has perhaps popular equivalents to something like aesthetic inconvenience. If any action is to be taken to protect the environment, it does not start with any selfabnegation by denying themselves an immediate higher standard of living as opposed to a lower one for the sake of their unborn grand-children. Even for those directly involved the environment is a cause not a personal reality.

For most people the facts of science and the facts of religion are in practical terms both dogma; they are believed in rather than understood. Perhaps the only difference lies in the fact that 
the former are based on human calculation and thus have no emotional pull and long-term validity if the history of science is anything to go by, while the dogmas of religion provide answers and emotions which science can never create or dispel.

There is little reason to suppose that the majority of the world's population grappling with persistent short-term insecurity will be any less likely than in the past to see their interests as best protected by violent confrontations based in many cases on religion by which the environment is destroyed in the short term for perhaps the longer term benefits of mankind.

KEYWORDS Violence. Environment. Religion. Contemporary.

ABSTRACT The implications of current approaches to changes in the environment are that reason and voluntary actions are the only acceptable ways of offsetting deleterious environmental actions. Thus any form of biological regulation is to be deplored and prevented, and further any Malthusian checks on environmental deterioration by means of war, famine and disease cannot be considered as viable options. There is also the possibly in our thinking of the remnants of nineteenth century ascent of man optimism that the decisions of man, collectively and individually, are based on the calm considerations of logic and compromise. This paper considers these views in the light of current affairs in which religion is the principal component and which has actively affected the environment.

\section{REFERENCES}

Benedict, P.: The Huguenot Population of France.1600-85. Philadelphia:Temple University, Philadelphia (1991).

Blickle, P.: The Revolution of 1525. The German Peasants War from a New Perspective. John Hopkins University, Baltimore (1981).

Boardman, E.P.: Christian Influences Upon the Ideology of the Taiping Rebellion. University of Wisconsin, Madison (1952).

Boyajian, D.H.: Armenia; the Case for a Forgotten Genocide.

Crafters, New Jersey (1972).

Chapple, C.: Non-injury to animals:Jaina and Buddhist per spectives'. In: T.Regan.(Ed.): Animal sacrifice.Religious perspec tives on the use of animals in science. Philadelphia: Temple University Press, Philadelphia (1972).

Dundas, P.: The Jains. Routledge, London (1992).

Francaviglia, R.V.: The Mormon Landscape. Existence, Creation and Perception of a Unique Image in the American West. A.M.S. Press, New York (1978).

Gaffney, P.D.: The Prophet's Pulpit. Islamic Preaching in Contemporary Egypt. University of California, Berkeley (1994).

Groussert, R.: The Empire of the Steppes. New Jersey (1970).

Hickley, J.: Religion and the Northern Ireland Problem.
Barnes and Noble. Totowa, New Jersey (1984).

Hookham, H.: Tamburlane the Conqueror, London (1962).

Hostetler, J.A.: Amish Society. John Hopkins University Press, Baltimore (1970).

Hostetler, J.A. and Huntington, G.E.: The Hutterites in North America. Rinehart and Winston, New York (1974).

Husaini, S.W.A.: Islamic Environmental Systems. Engineering. Macmillan, Basingstoke (1980)

Izzedine, C. (no date.). Le cholera et l'hygiene a la Mecque.

Juergensmeyer, M.: The New Cold War. Religious Nationalism Confronts the Secular State. University of California, Berkeley (1991).

Knutsson, K.E. and Selinus, R.: 'Fasting in Ethiopia. An anthropological and nutritional study'. American $J$ Clinical Nutrition., 23(9): 56-9 (1970).

Lal, B.K.: Hindu perspectives on the use of animals in science'. In: T.Regan. (Ed). Animal Sacrifice. Religious Perspectives on the Use of Animals in Science. Temple University Press, Philadelphia (1986).

Lamb, T.: Tamerlane, the Earth Shaker. New York (1932).

Levy, G.: Religion and Revolution. Oxford University Press, New York (1974).

Long, D.E.: The Haij Today. A Survey of The Contemporary Makkah Pilgrimage. State University of New York, New York (1979).

Maslow, A.H.: Motivation and Personality. Harper \& Row, New York (1987).

Menendez, A.J.: The Bitter Harvest. Church and State in Northern Ireland. Robert. B. Luce, Washington, DC (1973).

Michall, F.: The Taiping Rebellion. University of Washington, Seattle (1966).

Oliver, S.: Historia Damiatana.Bibliothek der literarischen. Vereins in Stuttgart, Tubingen (1894).

O'Malley, P.: The Uncivil War:Ireland Today. Houghton. Mifflin, Boston (1983)

Rapoport, D.C.:'Terror and the Messiah; an ancient experience and some modern parallels'. In: D.C. Rapoport and Y. Alexander (Eds): The Morality of Terrorism. Religious and Secular Justification. Pergamon Press, New York (1982).

Reynolds,V. and Tanner, R.:The Biology of Religion. Longmans, London (1983).

Reynolds, V. and Tanner, R.: The Social Ecology of Religion. Oxford University Press, New York (1995).

Richardson, L.F.: 'Statistics of deadly quarrels'. In: T.H. Pear (Ed.): Psychological Factors of Peace and War. Hutchinson, London (1950).

Sen, A.: Asoka's Edicts. Institute of Ideology, Calcutta (1956).

Sherrard, P.: The desanctification of nature. In: D. Baker (Ed). Sanctity and Secularity: The Church and The World. Blackwell, Oxford (1973).

Uden, M.H.F. van and Pieper, J.Z.T.: Christian Pilgrimages. Current Studies on Rituals. Perspectives for the Psychology of Religion (1956).

Wilkie, J.W.: The meaning of the Cristero war against the Mexican revolution. Journal Church and State.,viii (1990)

Wilkinson, D.: Deadly Quarrels. Lewis. F. Richardson and the Statistical Study of War. University of California, Berkeley (1980).

Wolfe, M.: The Hadj. A Pilgrimage to Mecca. Secker and Warburg, London (1994).

Wright,Q.: A Study of War: University of Chicago, Chicago (1984).

Authors'Addresses: R.E.S. Tanner, The Footprint, Padworth Common, Berks, RG7 4GG, U.K. C.J. Pawson, School of Psychology, University of East London, London, U.K. 